Supplement of Clim. Past, 16, 1987-1998, 2020

https://doi.org/10.5194/cp-16-1987-2020-supplement

(c) Author(s) 2020. This work is distributed under

the Creative Commons Attribution 4.0 License.

(c) (i)

Supplement of

\title{
Wet-dry status change in global closed basins between the mid-Holocene and the Last Glacial Maximum and its implication for future projection
}

Xinzhong Zhang et al.

Correspondence to: Yu Li (liyu@1zu.edu.cn)

The copyright of individual parts of the supplement might differ from the CC BY 4.0 License. 
Table S1. Wet/dry status change from new compilation of proxy records. "+"/ "-" indicates wetter/drier climate from lake records or more/less effective precipitation from multi-models during the MH than that during the LGM.

\begin{tabular}{|c|c|c|c|c|c|c|c|}
\hline Lake name & Country & Lon $\left({ }^{\circ} \mathrm{E}\right)$ & Lat $\left({ }^{\circ} \mathrm{N}\right)$ & Elev (m) & Records & Models & References \\
\hline Surprise & USA & -120.1 & 41.5 & 1370 & - & - & (Ibarra et al., 2014) \\
\hline Lahontan & USA & -119.5 & 40 & 1180 & - & - & (Benson et al., 2013) \\
\hline Owens & USA & -119 & 38 & 1080 & - & - & (Bacon et al., 2003) \\
\hline Mojave & USA & -116.8 & 36 & -60 & - & - & (Wells et al., 2003) \\
\hline Franklin & USA & -115.3 & 40.3 & 1820 & - & - & (Munroe \& Laabs, 2013) \\
\hline Clover & USA & -114.6 & 40.9 & 1700 & - & - & (Munroe \& Laabs, 2013) \\
\hline Bonneville & USA & -113 & 40.5 & 1280 & - & - & (Oviatt, 2015) \\
\hline Estancia & USA & -105.6 & 34.6 & 1860 & - & - & (Allen \& Anderson, 2000) \\
\hline Santiaguillo & Mexico & -104.8 & 24.8 & 1960 & - & - & (Chávez-Lara et al., 2015) \\
\hline Pátzcuaro & Mexico & -101.6 & 19.6 & 2040 & - & + & (Bradbury, 2000) \\
\hline Huelmo & Chile & -73 & -41.5 & 10 & - & - & (Massaferro et al., 2009) \\
\hline Tagua Tagua & Chile & -71.2 & -34.5 & 200 & - & - & (Valero-Garcés et al., 2005) \\
\hline Potrok Aike & Argentina & -70.4 & -52 & 110 & - & - & (Kliem et al., 2013) \\
\hline Cari Laufquen & Argentina & -69.6 & -41.4 & 790 & - & + & (Cartwright et al., 2011) \\
\hline Titicaca & Peru/Bolivia & -69.4 & -16 & 3800 & - & + & (Rowe et al., 2002) \\
\hline Uyuni & Bolivia & -67.5 & -20.2 & 3650 & - & - & (Baker et al., 2001) \\
\hline Pozuelos & Argentina & -66 & -22.4 & 3660 & - & + & (McGlue et al., 2013) \\
\hline Bosumtwi & Ghana & -1.4 & 6.5 & 150 & + & + & (Shanahan et al., 2006) \\
\hline Chad & Chad et al. & 14 & 13 & 280 & + & - & (Armitage et al., 2015) \\
\hline Ngami & Botswana & 22.7 & -20.5 & 920 & - & - & (Burrough et al., 2007) \\
\hline Tanganyika & Burundi & 29.8 & -6.7 & 773 & + & + & (Felton et al., 2007) \\
\hline Albert & Congo/Uganda & 31 & 1.5 & 615 & + & + & (Talbot et al., 2000) \\
\hline Rukwa & Tanzania & 32 & -8 & 800 & + & + & (Thevenon et al., 2002) \\
\hline Victoria & Tanzania et al. & 33 & -1 & 1135 & + & - & (Talbot \& Lærdal, 2000) \\
\hline Tuz & Turkey & 33.4 & 38.7 & 905 & - & - & (Doğan, 2010) \\
\hline Masoko & Tanzania & 33.8 & -9.3 & 840 & + & + & (Garcin et al., 2006) \\
\hline Malawi & Malawi et al. & 34.23 & -10 & 468 & + & - & (Johnson et al., 2002) \\
\hline Lisan & Israel et al. & 35.5 & 31.5 & -430 & - & - & (Bartov et al., 2002) \\
\hline Turkana & Kenya/Ethiopia & 36.1 & 3.6 & 360 & + & + & (Morrissey et al., 2014) \\
\hline Challa & Kenya/Tanzania & 37.7 & -3.3 & 880 & + & - & (Moernaut et al., 2010) \\
\hline Abiyata & Ethiopia & 38.7 & 7.7 & 1573 & + & + & (Chalié \& Gasse, 2002) \\
\hline Van & Turkey & 43 & 38.5 & 1640 & + & - & (Çağatay et al., 2014) \\
\hline Urmia & Iran & 45.5 & 37.5 & 1267 & - & + & (Stevens et al., 2012) \\
\hline Zeribar & Iran & 46 & 35.5 & 1285 & - & - & (Stevens et al., 2001) \\
\hline Caspian Sea & Azerbaijan et al. & 50.7 & 41.7 & -28 & + & - & (Yanina et al., 2014) \\
\hline Aral Sea & Kazakhstan/Uzbekistan & 60 & 45 & 42 & + & - & (Boomer et al., 2000) \\
\hline Karakul & Tajikistan & 73.5 & 39 & 3915 & + & - & (Heinecke et al., 2017) \\
\hline
\end{tabular}




\begin{tabular}{cccccccc}
\hline Son Kul & Kyrgyzstan & 75 & 41.8 & 3016 & + & + & (Huang et al., 2014) \\
Issyk-Kul & Kyrgyzstan & 77.3 & 42.4 & 1607 & + & + & (Ricketts et al., 2001) \\
Zabuye & China & 84 & 31.6 & 4421 & - & + & (Wang et al., 2002) \\
Bosten & China & 87 & 42 & 1048 & + & - & (Huang et al., 2009) \\
Nam Co & China & 90.5 & 30.7 & 4718 & - & + & (Mügler et al., 2010) \\
Lop Nur & China & 91 & 40.8 & 780 & - & + & (Chao et al., 2009) \\
Hurleg & China & 96.9 & 37.3 & 2817 & + & - & (Zhao et al., 2007) \\
Chaka & China & 99.1 & 36.7 & 3200 & - & + & (Liu et al., 2008) \\
Genggahai & China & 100 & 36.1 & 2860 & - & + & (Qiang et al., 2013) \\
Qinghai & China & 100 & 38 & 3260 & + & + & (Jin et al., 2015) \\
Khubsugul & Mongolia & 100.5 & 51 & 1645 & + & + & (Fedotov et al., 2004) \\
Juyanze & China & 101.5 & 41.8 & 900 & - & - & (Hartmann et al., 2009) \\
Eyre & Australia & 137.4 & -28.4 & -15 & - & - & (Magee et al., 2004) \\
Frome & Australia & 139.9 & -30.6 & 1 & - & - & (Deckker et al., 2011) \\
Callabonna & Australia & 140 & -29.7 & 1 & - & - & (Cohen et al., 2012) \\
\hline
\end{tabular}

5 Table S2. Pearson correlation coefficients between AI and monthly NAO, SOI, PDO and TPI during 1979-2016. The bold numbers mean that correlation coefficients are statistically significant at 5\% level. SAM-South America, NAM-North America, SAF-Southern Africa, EAF-Eastern Africa, NAF-Northern Africa and Arabian peninsula, CEA-Central Eurasia, AUSAustralia, ALL-Global closed basins.

\begin{tabular}{rlrrrrrrrrrrrr}
\hline \multirow{2}{*}{ NAOO } & & 1 & 2 & 3 & 4 & 5 & 6 & 7 & 8 & 9 & 10 & 11 & 12 \\
& ALL & 0.25 & -0.03 & 0.15 & -0.03 & -0.02 & -0.02 & -0.09 & 0.10 & -0.03 & 0.19 & 0.06 & 0.12 \\
& SAM & -0.15 & 0.00 & 0.05 & -0.02 & 0.11 & 0.00 & 0.02 & -0.07 & $\mathbf{- 0 . 3 4}$ & 0.08 & 0.14 & 0.10 \\
& NAM & 0.01 & -0.08 & -0.11 & 0.10 & 0.11 & 0.07 & 0.09 & 0.10 & -0.17 & 0.18 & 0.18 & 0.45 \\
& SAF & -0.09 & -0.17 & 0.08 & 0.17 & 0.13 & $\mathbf{- 0 . 3 6}$ & -0.11 & -0.25 & 0.01 & -0.18 & -0.06 & -0.07 \\
& EAF & 0.19 & 0.12 & $\mathbf{0 . 4 1}$ & -0.04 & -0.10 & -0.06 & -0.07 & 0.11 & 0.30 & 0.29 & -0.03 & 0.03 \\
& NAF & 0.06 & -0.05 & 0.15 & 0.05 & -0.04 & -0.12 & 0.06 & -0.08 & 0.18 & -0.11 & -0.02 & 0.04 \\
& CEA & $\mathbf{0 . 3 7}$ & -0.05 & -0.08 & -0.16 & -0.04 & 0.14 & -0.04 & 0.18 & -0.12 & 0.05 & 0.01 & 0.02 \\
& AUS & -0.17 & 0.04 & -0.06 & 0.26 & -0.08 & -0.20 & -0.03 & -0.08 & -0.13 & -0.03 & 0.09 & 0.13 \\
SOI & ALL & $\mathbf{- 0 . 3 5}$ & $\mathbf{- 0 . 3 5}$ & $\mathbf{- 0 . 4 2}$ & $\mathbf{- 0 . 4 8}$ & -0.07 & 0.16 & 0.01 & 0.07 & -0.03 & 0.21 & 0.12 & -0.08 \\
& SAM & -0.17 & 0.02 & -0.10 & -0.24 & -0.32 & -0.22 & -0.27 & -0.06 & -0.16 & -0.15 & -0.05 & -0.25 \\
& NAM & -0.01 & -0.09 & -0.06 & -0.03 & -0.17 & -0.19 & -0.24 & -0.13 & -0.12 & -0.15 & -0.07 & 0.03 \\
& SAF & -0.06 & -0.01 & -0.15 & -0.01 & -0.07 & 0.08 & -0.01 & -0.05 & 0.07 & 0.17 & 0.14 & 0.10 \\
& EAF & -0.22 & $\mathbf{- 0 . 3 4}$ & $\mathbf{- 0 . 3 5}$ & -0.15 & 0.16 & 0.21 & 0.14 & 0.03 & 0.01 & 0.22 & -0.01 & 0.08 \\
& NAF & -0.17 & -0.13 & 0.07 & -0.15 & 0.22 & 0.07 & 0.02 & -0.02 & 0.18 & 0.15 & 0.05 & 0.09 \\
& CEA & -0.26 & -0.30 & $\mathbf{- 0 . 3 7}$ & $\mathbf{- 0 . 5 3}$ & -0.23 & 0.01 & -0.08 & 0.03 & -0.14 & -0.01 & -0.01 & -0.23 \\
& AUS & 0.19 & $\mathbf{0 . 3 9}$ & 0.27 & 0.13 & 0.07 & -0.14 & -0.08 & 0.01 & 0.09 & 0.11 & 0.21 & 0.04 \\
PDO & ALL & -0.04 & -0.20 & -0.14 & -0.09 & -0.18 & 0.04 & 0.06 & 0.13 & 0.07 & 0.14 & 0.10 & -0.05
\end{tabular}




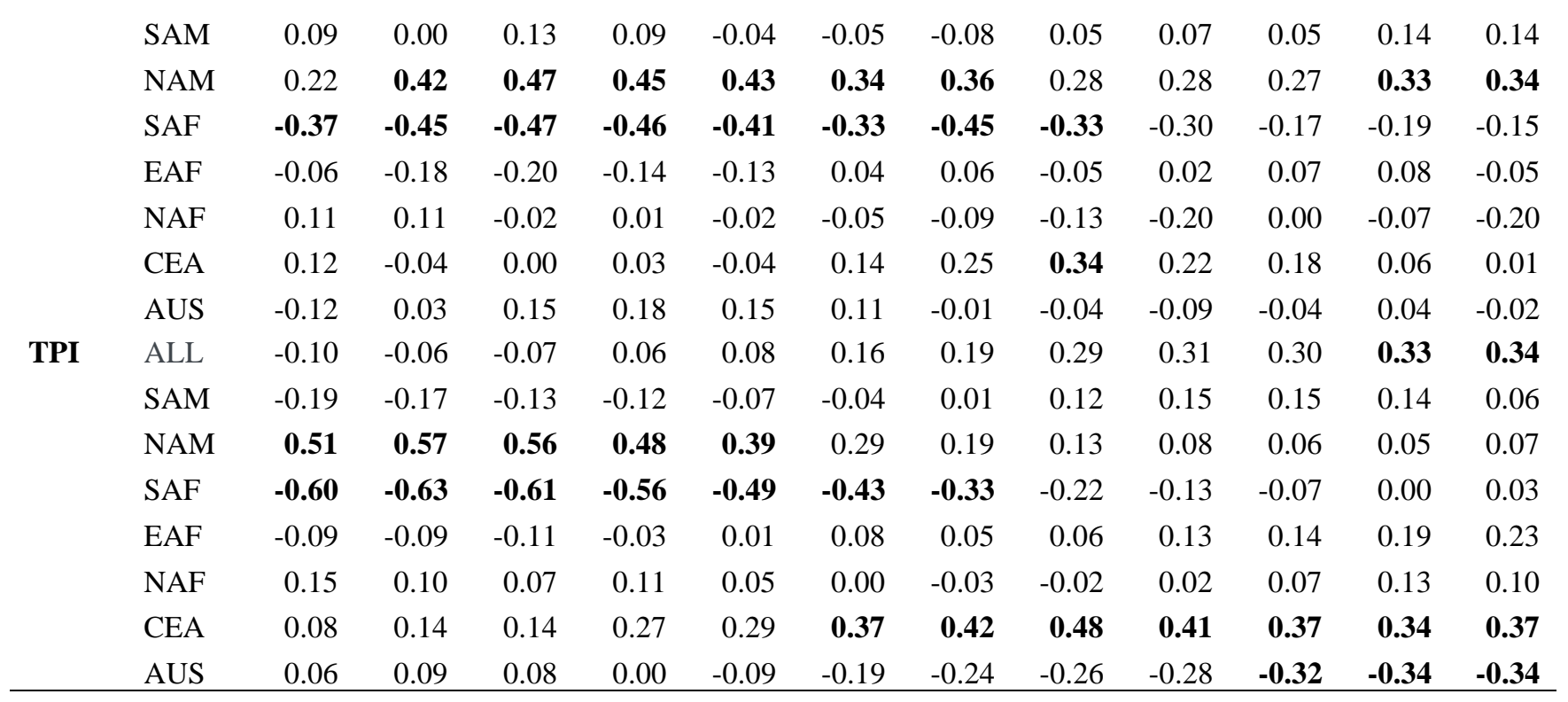

\section{References}

Allen, B. D., \& Anderson, R. Y. (2000). A continuous, high-resolution record of late Pleistocene climate variability from the Estancia basin, New Mexico. Geological Society of America Bulletin, 112(9), 1444-1458.

Armitage, S. J., Bristow, C. S., \& Drake, N. A. (2015). West African monsoon dynamics inferred from abrupt fluctuations of Lake Mega-Chad. Proceedings of the National Academy of Sciences, 112(28), 8543-8548.

15 Bacon, S. N., Burke, R. M., Pezzopane, S. K., \& Jayko, A. S. (2006). Last glacial maximum and Holocene lake levels of Owens Lake, eastern California, USA. Quaternary Science Reviews, 25(11-12), 1264-1282.

Baker, P. A., Rigsby, C. A., Seltzer, G. O., Fritz, S. C., Lowenstein, T. K., Bacher, N. P., \& Veliz, C. (2001). Tropical climate changes at millennial and orbital timescales on the Bolivian Altiplano. Nature, 409(6821), 698.

Bartov, Y., Stein, M., Enzel, Y., Agnon, A., \& Reches, Z. E. (2002). Lake levels and sequence stratigraphy of Lake Lisan, the late Pleistocene precursor of the Dead Sea. Quaternary Research, 57(1), 9-21.

Benson, L. V., Smoot, J. P., Lund, S. P., Mensing, S. A., Foit Jr, F. F., \& Rye, R. O. (2013). Insights from a synthesis of old and new climate-proxy data from the Pyramid and Winnemucca lake basins for the period 48 to 11.5 cal ka. Quaternary International, 310, 62-82.

Boomer, I., Aladin, N., Plotnikov, I., \& Whatley, R. (2000). The palaeolimnology of the Aral Sea: a review. Quaternary Science Reviews, 19(13), 1259-1278.

Bradbury, J. P. (2000). Limnologic history of Lago de Patzcuaro, Michoacan, Mexico for the past 48,000 years: impacts of climate and man. Palaeogeography, Palaeoclimatology, Palaeoecology, 163(1-2), 69-95. 
Burrough, S. L., Thomas, D. S. G., Shaw, P. A., \& Bailey, R. M. (2007). Multiphase quaternary highstands at lake ngami, kalahari, northern botswana. Palaeogeography, Palaeoclimatology, Palaeoecology, 253(3-4), 280-299.

30 Çağatay, M. N., Öğretmen, N., Damcl, E., Stockhecke, M., Sancar, Ü., Eriş, K. K., \& Özeren, S. (2014). Lake level and climate records of the last $90 \mathrm{ka}$ from the Northern Basin of Lake Van, eastern Turkey. Quaternary Science Reviews, 104, 97-116.

Cartwright, A., Quade, J., Stine, S., Adams, K. D., Broecker, W., \& Cheng, H. (2011). Chronostratigraphy and lake-level changes of Laguna Cari-Laufquén, Río Negro, Argentina. Quaternary Research, 76(3), 430-440.

Chalié, F., \& Gasse, F. (2002). Late Glacial-Holocene diatom record of water chemistry and lake level change from the tropical East African Rift Lake Abiyata (Ethiopia). Palaeogeography, Palaeoclimatology, Palaeoecology, 187(3-4), $259-283$.

Chao, L., Zicheng, P., Dong, Y., Weiguo, L., Zhaofeng, Z., Jianfeng, H., \& Chenlin, C. (2009). A lacustrine record from Lop Nur, Xinjiang, China: Implications for paleoclimate change during Late Pleistocene. Journal of Asian Earth Sciences, 34(1), $38-45$.

Chávez-Lara, C. M., Roy, P. D., Pérez, L., Sankar, G. M., \& Neri, V. H. L. (2015). Ostracode and C/N based paleoecological record from Santiaguillo basin of subtropical Mexico over last 27 cal kyr BP. Revista Mexicana de Ciencias Geológicas, 32(1), 1-10.

Cohen, T. J., Nanson, G. C., Jansen, J. D., Jones, B. G., Jacobs, Z., Larsen, J. R., May, J. H., Treble, P., Price, D. M., \& Smith, A. M. (2012). Late Quaternary mega-lakes fed by the northern and southern river systems of central Australia: varying moisture sources and increased continental aridity. Palaeogeography, Palaeoclimatology, Palaeoecology, 356, 89-108.

Deckker, P. D. , Magee, J. W. , \& Shelley, J. M. G. . (2011). Late quaternary palaeohydrological changes in the large playa lake frome in central australia, recorded from the $\mathrm{mg} / \mathrm{ca}$ and sr/ca in ostracod valves and biotic remains. Journal of Arid Environments, 75(1), 38-50.

Doğan, U. (2010). Fluvial response to climate change during and after the Last Glacial Maximum in Central Anatolia, Turkey. Quaternary International, 222(1-2), 221-229.

50 Fedotov, A. P., Chebykin, E. P., Semenov, M. Y., Vorobyova, S. S., Osipov, E. Y., Golobokova, L. P., Pogodaeva, T. V., Zheleznyakova, T. O., Grachev, M. A., Tomurhuu, D., Oyunchimeg, T., Narantsetseg, T., Tomurtogoo, O., Dolgikh, P. T., Arsenyuk, M. I., \& Batist, M. D. (2004). Changes in the volume and salinity of Lake Khubsugul (Mongolia) in response to global climate changes in the upper Pleistocene and the Holocene. Palaeogeography, Palaeoclimatology, Palaeoecology, 209(1-4), 245-257.

55 Felton, A. A., Russell, J. M., Cohen, A. S., Baker, M. E., Chesley, J. T., Lezzar, K. E., McGlue, M. M., Pigati, J. S., Quade, J., Stager, J. C., \& Tiercelin, J. J. (2007). Paleolimnological evidence for the onset and termination of glacial aridity from Lake Tanganyika, Tropical East Africa. Palaeogeography, Palaeoclimatology, Palaeoecology, 252(3-4), 405-423.

Garcin, Y., Vincens, A. , Williamson, D. , Guiot, J. , \& Buchet, G. . (2006). Wet phases in tropical southern africa during the last glacial period. Geophysical Research Letters, 33(7), L07703.

60 Hartmann, K., \& Wünnemann, B. (2009). Hydrological changes and Holocene climate variations in NW China, inferred from lake sediments of Juyanze palaeolake by factor analyses. Quaternary International, 194(1-2), 28-44. 
Heinecke, L., Mischke, S., Adler, K., Barth, A., Biskaborn, B. K., Plessen, B., Nitze, I., Kuhn, G., Rajabov, I., \& Herzschuh, U. (2017). Climatic and limnological changes at Lake Karakul (Tajikistan) during the last 29 cal ka. Journal of Paleolimnology, 58(3), 317-334.

65 Huang, X. Z., Chen, F. H., Fan, Y. X., \& Yang, M. L. (2009). Dry late-glacial and early Holocene climate in arid central Asia indicated by lithological and palynological evidence from Bosten Lake, China. Quaternary International, 194(1-2), 19-27.

Huang, X., Oberhänsli, H., von Suchodoletz, H., Prasad, S., Sorrel, P., Plessen, B., Mathis, M., \& Usubaliev, R. (2014). Hydrological changes in western Central Asia (Kyrgyzstan) during the Holocene as inferred from a palaeolimnological study in lake Son Kul. Quaternary Science Reviews, 103, 134-152.

70 Ibarra, D. E., Egger, A. E., Weaver, K. L., Harris, C. R., \& Maher, K. (2014). Rise and fall of late Pleistocene pluvial lakes in response to reduced evaporation and precipitation: Evidence from Lake Surprise, California. Bulletin, 126(11-12), 13871415.

Jin, Z., An, Z., Yu, J., Li, F., \& Zhang, F. (2015). Lake Qinghai sediment geochemistry linked to hydroclimate variability since the last glacial. Quaternary Science Reviews, 122, 63-73.

75 Johnson, T. C., Brown, E. T., McManus, J., Barry, S., Barker, P., \& Gasse, F. (2002). A high-resolution paleoclimate record spanning the past 25,000 years in southern East Africa. Science, 296(5565), 113-132.

Kliem, P., Buylaert, J. P., Hahn, A., Mayr, C., Murray, A. S., Ohlendorf, C., Veres, D., Wastegård, S., Zolitschka, B., \& the PASADO science team. (2013). Magnitude, geomorphologic response and climate links of lake level oscillations at Laguna Potrok Aike, Patagonian steppe (Argentina). Quaternary Science Reviews, 71, 131-146.

80 Liu, X., Dong, H., Rech, J. A., Matsumoto, R., Yang, B., \& Wang, Y. (2008). Evolution of Chaka Salt Lake in NW China in response to climatic change during the Latest Pleistocene-Holocene. Quaternary Science Reviews, 27(7-8), 867-879.

Magee, J. W., Miller, G. H., Spooner, N. A., \& Questiaux, D. (2004). Continuous 150 ky monsoon record from Lake Eyre, Australia: insolation-forcing implications and unexpected Holocene failure. Geology, 32(10), 885-888.

Massaferro, J. I., Moreno, P. I., Denton, G. H., Vandergoes, M., \& Dieffenbacher-Krall, A. (2009). Chironomid and pollen evidence for climate fluctuations during the Last Glacial Termination in NW Patagonia. Quaternary Science Reviews, 28(56), 517-525.

McGlue, M. M., Cohen, A. S., Ellis, G. S., \& Kowler, A. L. (2013). Late Quaternary stratigraphy, sedimentologyand geochemistryof an underfilled lake basin in the Puna plateau (northwest Argentina). Basin Research, 25(6), 638-658.

Moernaut, J., Verschuren, D., Charlet, F., Kristen, I., Fagot, M., \& DeBatist, M. (2010). The seismic-stratigraphic record of lake-level fluctuations in Lake Challa: Hydrological stability and change in equatorial East Africa over the last 140 kyr. Earth and Planetary Science Letters, 290(1-2), 214-223.

Morrissey, A. , \& Scholz, C. A. . (2014). Paleohydrology of lake turkana and its influence on the nile river system. Palaeogeography, Palaeoclimatology, Palaeoecology, 403, 88-100. 
Mügler, I., Gleixner, G., Günther, F., Mäusbacher, R., Daut, G., Schütt, B., Berking, J., Schwark, L., Xu, B., Yao, T., Zhu, L., \& Yi, C. (2010). A multi-proxy approach to reconstruct hydrological changes and Holocene climate development of Nam Co, Central Tibet. Journal of Paleolimnology, 43(4), 625-648.

Munroe, J. S., \& Laabs, B. J. (2013). Temporal correspondence between pluvial lake highstands in the southwestern US and Heinrich Event 1. Journal of Quaternary Science, 28(1), 49-58.

Oviatt, C. G. (2015). Chronology of Lake Bonneville, 30,000 to 10,000 yr BP. Quaternary Science Reviews, 110, $166-171$.

100 Qiang, M., Song, L., Chen, F., Li, M., Liu, X., \& Wang, Q. (2013). A 16-ka lake-level record inferred from macrofossils in a sediment core from Genggahai Lake, northeastern Qinghai-Tibetan Plateau (China). Journal of Paleolimnology, 49(4), 575590.

Ricketts, R. D., Johnson, T. C., Brown, E. T., Rasmussen, K. A., \& Romanovsky, V. V. (2001). The Holocene paleolimnology of Lake Issyk-Kul, Kyrgyzstan: Trace element and stable isotope composition of ostracodes. Palaeogeography, Palaeoclimatology, Palaeoecology, 176(1-4), 207-227.

Rowe, H. D., Dunbar, R. B., Mucciarone, D. A., Seltzer, G. O., Baker, P. A., \& Fritz, S. (2002). Insolation, moisture balance and climate change on the South American Altiplano since the Last Glacial Maximum. Climatic Change, 52(1-2), 175-199.

Shanahan, T. M., Overpeck, J. T., Wheeler, C. W., Beck, J. W., Pigati, J. S., Talbot, M. R., Scholz, C. A., Peck,J., \& King, J. W. (2006). Paleoclimatic variations in West Africa from a record of late Pleistocene and Holocene lake level stands of Lake Bosumtwi, Ghana. Palaeogeography, Palaeoclimatology, Palaeoecology, 242(3-4), 287-302.

Stevens, L. R., Djamali, M., Andrieu-Ponel, V., \& deBeaulieu, J. L. (2012). Hydroclimatic variations over the last two glacial/interglacial cycles at Lake Urmia, Iran. Journal of Paleolimnology, 47(4), 645-660.

Stevens, L. R., Wright Jr, H. E., \& Ito, E. (2001). Proposed changes in seasonality of climate during the Lateglacial and Holocene at Lake Zeribar, Iran. The Holocene, 11(6), 747-755.

115 Talbot, M. R., \& Lærdal, T. (2000). The Late Pleistocene-Holocene palaeolimnology of Lake Victoria, East Africa, based upon elemental and isotopic analyses of sedimentary organic matter. Journal of Paleolimnology, 23(2), 141 -164.

Talbot, M. R., Williams, M. A. J., \& Adamson, D. A. (2000). Strontium isotope evidence for late Pleistocene reestablishment of an integrated Nile drainage network. Geology, 28(4), 343-346.

Thevenon, F., Williamson, D., \& Taieb, M. (2002). A 22 kyr BP sedimentological record of Lake Rukwa (8 S, SW Tanzania): environmental, chronostratigraphic and climatic implications. Palaeogeography, Palaeoclimatology, Palaeoecology, 187(34), 285-294.

Valero-Garcés, B. L., Jenny, B., Rondanelli, M., Delgado-Huertas, A., Burns, S. J., Veit, H., \& Moreno, A. (2005). Palaeohydrology of Laguna de Tagua Tagua $\left(34^{\circ} 30^{\prime} \mathrm{S}\right)$ and moisture fluctuations in Central Chile for the last 46000 yr. Journal of Quaternary Science: Published for the Quaternary Research Association, 20(7-8), 625-641.

125 Wang, R. L., Scarpitta, S. C., Zhang, S. C., \& Zheng, M. P. (2002). Later Pleistocene/Holocene climate conditions of QinghaiXizhang Plateau (Tibet) based on carbon and oxygen stable isotopes of Zabuye Lake sediments. Earth and Planetary Science Letters, 203(1), 461-477. 
Wells, S. G., Brown, W. J., Enzel, Y., Anderson, R. Y., McFadden, L. D., \& Lancaster, N. (2003). Late Quaternary geology and paleohydrology of pluvial Lake Mojave, southern California. Special Papers-Geological Society of America, 79-114.

130 Yanina, T. A. (2014). The Ponto-Caspian region: environmental consequences of climate change during the Late Pleistocene. Quaternary International, 345, 88-99.

Zhao, Y., Yu, Z., Chen, F., Ito, E., \& Zhao, C. (2007). Holocene vegetation and climate history at Hurleg Lake in the Qaidam Basin, northwest China. Review of Palaeobotany and Palynology, 145(3-4), 275-288. 